\title{
ECOLOGY
}

DOI https://doi.org/10.30525/978-9934-26-047-6-11

\section{ВПЛИВ ЕКЗОМЕТАБОЛІТІВ КУЛЬТУРНИХ РОСЛИН НА ПРОРОСТАННЯ КОНІДІЙ МІКОМІЦТТВ РОДУ FUSARIUM LINK}

\author{
Безноско I.B. \\ кандидат біологічних наук, \\ старший науковий співробітник лабораторії біоконтролю \\ агроекосистем і органічного виробництва \\ Інститут агроекології і природокористування \\ Національної академії аграрних наук України
}

\section{Горган Т. М. \\ аспірантка,}

науковий співробітник лабораторії біоконтролю агроекосистем

і органічного виробництва

Інститут агроекології і природокористування

Національної академії аграрних наук Украӥни

м. Київ, Украӥна

Необхідність виробництва якісної рослинної продукції вимагає подальшого розв'язання низки проблем, зокрема обумовлених взаємодією популяцій фітопатогенних мікроміцетів 3 сортом культурних рослин - біотичним екологічним чинником формування фітопатогенного фону в агрофітоценозах. Усі активні захисні реакції рослини пов'язані з істотними змінами в обміні речовин як рослини, так і паразита. Від характеру цих змін у рослини-живителя залежить результат взаємодії, тобто загибель паразита або ураження рослини $[3$, с. $248 ; 4$, с. 155$]$.

Відомо, $[11$, с. $584 ; 12$, с. 200]. що в процесі життєдіяльності рослин в оточуюче середовище через кореневу систему виділяється 23-30\% загального вмісту речовин. Кореневі екзометаболіти захищають проростаюче насіння, проростки і рослини від збудників хвороб, виявляють фунгіцидні та бактерицидні властивості, що обумовлюються комплексом біологічно активних речовин [14, с. 19; 16, с. 172]. 
Проаналізовано особливості формування фітопатогенного фону мікроміцетів, збудників хвороб культурних рослин, в умовах органічного виробництва. У фітопатогенному комплексі провідне місце займають мікроміцети, серед яких домінують збудники різновидів кореневих гнилей.

Площа посівів, уражених цими хворобами, коливається від 32,5 до $75,0 \%$, а у деякі роки сягає $100 \%$ [9, с. 40]. Також, за даними джерел літератури [1, с.14], потепління клімату, особливо в зимові місяці, спричиняс розширення ареалу патогенів на території, де раніше вони не траплялись.

Мікоміцети роду Fusarium - це найбільш варіабельні і рухомі патогени, які мають гетерокаріозний міцелій i конідії [9, с.195; 10, с. 117-127 ]. Одним із найпоширеніших збудників фузаріозів злакових культур $є F$. oxysporum $[8$, c. 5-15]. 3 літературних джерел, також, відомо, що останнім часом серед фузаріозів цибулевих переважас мікроміцет $F$. proliferatum $[13$, c. $94-110 ; 15$, с. $285-293]$

Під дією біотичних i абіотичних факторів навколишнього середовища мікроміцети здатні змінювати свої життєві стратегії та живитись як паразити на вегетуючих рослинах, або як сапротрофи на відмерлих рештках у грунті. Відомо, що субстрат, на якому розвивається гриб, є головним регулятором його життєдіяльності [16, с. 472-479]. Тому метою нашого дослідження було визначення впливу екзометаболітів культурних рослин на здатність проростання конідій мікоміцетів $F$. oxysporum та $F$. proliferatum.

Дослідження проводили в лабораторії біоконтролю агроекосистем і органічного виробництва Інституту агроекології i природокористування НААН. Для проведення досліджень використовували метаболіти 14 сортів різних культур, а саме, чотирьох сортів пшениці озимої: Подолянка, Наталка, Скаген, Мулан; трьох сортів вівсу: Скарб України, Тембр, Світанок та семи сортів цибулі ріпчастої Ткаченківська, Мавка, Веселка, Любчик, Варяг, Гармонія, Голубка.

Для отримання метаболітів культурних рослин різних сортів, відбирали по 50 насінин кожного досліджуваного сорту. Насіння замочували у воді й витримували впродовж 3-8 діб в залежності від фізіологічних особливостей культури до формування проростків довжиною 2-3 см. По 10 проростків кожного сорту поміщали у чашки Петрі зі стерильною дистильованою водою, де витримували впродовж 72 год на розсіяному світлі при температурі $22-24^{\circ} \mathrm{C}$. Ексудати змивали і фільтрували через мікропористий бактеріальний фільтр (0,02 мкм) $[5$, c. $1-3 ; 6$, c. $1-6]$.

Для вивчення впливу екзометаболітів різних сортів культурних рослин на проростання конідій мікроміцетів $F$. oxysporum $F$. Prolife46 
ratum використовували відому методику, яка включає пророщування спор на предметних скельцях у водному агарі [2. с. 12-14]. За проростанням конідій спостерігали протягом 6, 12, 24 та 48 годин. Контролем у даному дослідженні була дистильована вода.

Підчас дослідження було виявлено, що оптимальним часом для підрахунку пророслих конідій є 24 годин після посіву мікроміцету $F$. oxysporum та 12 годин для $F$. proliferatum, коли росткова трубка перевищує розмір конідії i має оптимальний розмір, щоб не ускладнювати підрахунок.

Репродуктивна здатність мікроміцету $F$. oxysporum за впливу екзометаболітів різних сортів культурних рослин диференціювалася по різному залежно від сорту і його фізіолого-біохімічних властивостей.

Екзометаболіти пшениці озимої сортів Наталка і Скаген характеризувалися високим відсотком проростання конідій, досліджуваного мікроміцету, що становив 55-60\%. В той же час, за впливу екзометаболітів пшениці озимої сортів Мулан і Подолянка відсоток проростання спор був істотно нижчий, що становив 35-40\%. Визначено, що екзометаболіти, досліджуваних сортів пшениці озимої, здатні пригнічувати проростання конідій мікроміцету $F$. oxysporum, порівняно 3 контролем, де відсоток проростання конідій мікроміцету становив $80 \%$.

Екзометаболіти сортів вівса характеризувалися істотно низьким відсотком проростання конідій, який становив 20-30\%, що майже в три рази менший за контроль.

У дослідженні мікроміцету $F$. proliferatum ексудати сортів цибулі ріпчастої пригнічували проростання спор гриба в порівнянні 3 контролем, що становив 84\%. Вплив екзометаболітів сортів Ткаченківська, Мавка, Веселка та Любчик на конідії досліджуваного мікроміцету був найнижчім і варіював в діапазоні 42-61\% пророслих інфекційних структур.

Натомість, ексудати сортів Варяг, Гармонія та Голубка спричиняли більший тиск на мікроміцет $F$. proliferatum. Вітсоток проростання спор в даних зразках коливався в межах $20-37 \%$.

Отже, екзометаболіти сортів культурних рослин мають різний рівень стимулюючої дії на проростання конідій мікроміцетів $F$. oxysporu та $F$. proliferatum, що важливо при відтворенні життєдіяльності спочиваючих структур гриба після зберігання в рослинних рештках та грунті.

Дослідження в цьому напрямі поглиблюють знання процесу взаємодії мікроміцетів зі сортами культурних рослин і розкривають нові можливості біологічного контролю чисельності фітопатогенних грибів в агроекосистемах. Це забезпечить підвищення якості рослинної 
продукції та знизить рівень антропогенного впливу на навколишнє природне середовище.

\section{Література:}

1. Левитин М.М. Изменение климата и прогноз развития болезней растений. Микология и фитопатология, 2012, № 46. С. 14-19.

2. Лемеза Н.А. Иммунитет растений: практикум [для студентов биол. фак.]. Минск: БГУ, 2008. 96 с.

3. Парфенюк А.І. Сорти сільськогосподарських культур, як фактор біоконтролю фітопатогенних мікроорганізмів в агрофітоценозах. Агроекологічний журнал, 2009. Спец. випуск, С. 248-250

4. Парфенюк А.І. Сорт рослин як чинник біологічної безпеки в агроценозах України. Агроекологічний журнал, 2017. № 2. С. 155-163.

5. Патент 92066 Україна. Спосіб визначення впливу екзометаболітів культурних рослин на ріст i розвиток культур грибів некротрофного типу живлення. А.I Парфенюк., А.А Благініна, Т. М. Горган. Заявл. 11.03.2014; опубл. 25.07.2014. Бюл. № 14.

6. Петюх Г.П., Подоба Ю.В. Визначення стимуляції росту діазотрофних бактерій ексудатами проростків ячменю: методичні рекомендації. К.: Логос, 2004. 13 с.

7. Пшедецкая Л.И., Серов Г.И., Николаев П.М. [и др.].Экология грибов: теоритические и прикладные аспекты. СПб.: Биол. НИИСПГУ, 1992. $245 \mathrm{c}$.

8. Швартау В.В.,. Зозуля О.Л, Михальська Л.М., Санін О.Ю. Фузаріози культурних рослин. Монографія. К.: Логос, 2016. 164 с.

9. Швартау В.В. Михальська Л.М. Зозуля О.Л. Поширення фузаріозів в Україні. Агроном, 2017, № 4, С. 40-43.

10. Brett A. Summerell, Baharuddin Salleh, John F. Leslie A Utilitarian Approach to Fusarium Identification. Plant Disease, 2003. Vol. 87. No. 2. P. 117-128.

11. Elijarrat E., Barcelo D. Sample handling and analysis of allelochemical compounds in plants. Trends Anal. Chem. 2001. V. 20. P. 584-590.

12. Inderjit, Mukerji K.G. Allelochemicals: biological control of plant pathogens and diseases. Dordrecht: Springer, 2006. 208 p.

13. Kintega, K.R., Zida, P.E., Tarpaga, V.W., Sankara, P. and Sereme, P.Identification of Fusarium Species Associated with Onion (Allium cepa L.) Plants in Field in Burkina Faso. Advances in Bioscience and Biotechnology, 2020, 11, P. 94-110.

14. Latif S., Chiapusio G., Weston L.A. Chapter Two - Allelopathy and the role of allelochemicals in plant defense. Adv. Bot. Res. 2017. V. 82. P. 19-54. 
15. Paul L. Chretien, Sandrine Laurent, Isabelle Bornard, Claire Troulet, Mohamed El Maâtaoui, et al.. Unraveling the infection process of garlic by Fusarium proliferatum, the causal agent of root rot. Phytopathologia Mediterranea, Firenze University Press, 2020. № 59. P. 285-293.

16. Weir T.L., Park S.W., Vivanco J.M. Biochemical and physiological mechanisms mediated by allelochemicals. Curr. Opin. Plant Biol. 2004. V. 7. P. 472-479.

DOI https://doi.org/10.30525/978-9934-26-047-6-12

\title{
TYPOLOGICAL DIVERSITY OF FORESTS IN THE CATCHMENT AREAS OF THE RIVERS OF THE LEFT-BANK FOREST-STEPPE
}

\author{
Bondar O. B. \\ Candidate of Agricultural Sciences (Ph. D.), \\ Senior Lecturer at the Department of Biology, \\ Ecology and Methods of Teaching \\ Taras Shevchenko Regional Humanitarian-Pedagogical Academy \\ of Kremenets \\ Kremenets, Ternopil region, Ukraine \\ Tkach L. I. \\ Candidate of Agricultural Sciences (Ph. D.), \\ Associate Professor at the Engineering Ecology of Cities \\ O. M. Beketov National University of Urban Economy in Kharkiv \\ Kharkiv, Ukraine \\ Halahan O. K. \\ Candidate of Biological Sciences (Ph. D.), \\ Associate Professor at the Biology, Ecology and Methods of Teaching \\ Taras Shevchenko Regional Humanitarian-Pedagogical Academy \\ of Kremenets \\ Kremenets, Ternopil region, Ukraine
}

Farm management in watershed year should be primarily aimed at strengthening of water protection and eco-stabilizing functions. Solution of these problems regarding preserving and enhancing of these functions is possible, taking into account typological characteristics of forests. These 